\title{
Optimum Planting Configuration for High Population Plasticulture Grown Cabbage
}

\author{
Charles E. Barrett, Lincoln Zotarelli ${ }^{1}$, and Lucas G. Paranhos \\ Horticultural Sciences Department, Institute of Food and Agricultural \\ Sciences, University of Florida, Gainesville, FL 32611 \\ Brian S. Taylor \\ Hastings Agricultural Extension Center, Institute of Food and Agricultural \\ Sciences, University of Florida, Hastings, FL 32145
}

Peter Dittmar

Horticultural Sciences Department, Institute of Food and Agricultural Sciences, University of Florida, Gainesville, FL 32611

Clyde W. Fraisse

Agricultural and Biological Engineering Department, Institute of Food and Agricultural Sciences, University of Florida, Gainesville, FL 32611

John VanSickle

Food and Resource Economics Department, Institute of Food and Agricultural Sciences, University of Florida, Gainesville, FL 32611

Additional index words. cabbage, Brassica oleracea var. capitata, drip irrigation, plastic mulch, in-row spacing, planting date, Florida

\begin{abstract}
Florida is a major fresh-market cabbage (Brassica oleracea $\mathbf{L}$. var. capitata) producing state in the United States. The current cabbage production system relies on bare ground and subirrigation that requires a large volume of water to irrigate the crop. The bare ground system facilitates a maximum of 48,438 plant/ha, while there is a potential to increase plant population per area using plasticulture and drip irrigation. The objectives of this study were to determine the optimum cabbage plant population and plant arrangement that maximizes marketable yield per area for a high cabbage population plasticulture system. Cabbage was grown on 1.2-m-wide raised beds with black plastic mulch and drip irrigation. Plants were grown in either three or four rows with in-row plant spacings ranging from 15 to $35 \mathrm{~cm}$ and plant populations ranging from 41,518 to 129,167 plants/ha. Cabbage marketable yield increased as in-row spacing increased. Yields ranged from 19.7 to $69.7 \mathrm{Mg} \cdot \mathrm{ha}^{-1}$. Marketable yield was not different between 3 and 4 rows for in-row spacings above $25 \mathrm{~cm}$. The 15 and $20 \mathrm{~cm}$ in-row spacing produced significantly lower yields in the 4-row configuration as compared with the 3-row configuration in Fall and Winter 2011. Wider in-row spacings produced a greater percentage of heads of marketable size while reducing the percentage of small heads when compared with narrower in-row spacings. Mean head weight increased as in-row spacing increased and a 3- or 4-row configuration with an in-row spacing between 25 and $30 \mathrm{~cm}$ had consistently high yields in all three seasons compared with narrower in-row plant spacings. These results indicated that with a high population plasticulture system variable plant populations could be selected. In-row plant spacings between 30 and $35 \mathrm{~cm}$ may be beneficial for early plantings while a $25-\mathrm{cm}$ spacing could be more productive for later plantings, especially when weather conditions are favorable.
\end{abstract}

Florida is the second largest fresh-market cabbage producer in the United States, with an annual value close to $\$ 50$ million (FDACS, 2014). Florida cabbage is produced during the fall and winter months (Boswell and Jones, 1941; Strandberg and White, 1979) to capture high market prices when other regions are unable to produce. Growing during this season positions Florida producers at risk of experiencing adverse weather conditions. Fall and winter months are characterized by wide variations in air temperature and potential nutrient losses from heavy rainfall events. Seepage irrigation (subirrigation) with broadcast fertilizer application dominates the cabbage industry in Florida, adding to the potential for nutrient loss. Seepage has low irrigation efficiency because it requires significant water withdrawals from surface or groundwater sources to maintain a high water table to irrigate the crop (Dukes et al., 2010). This type of production system facilitates off-site movement of soluble nutrients. Continued state population growth, recent droughts, saltwater intrusion, uncertainties associated with climate, and water conservation regulations have prompted growers to seek alternative production practices that conserve water, reduce the risk of nutrient losses, and allow for an increase in production. In addition, the need for more efficient use of water and fertilizers will only continue to gain importance as the demand and cost for these inputs increase (Cordell et al., 2009; Marella, 2014).

The current commercial production practices for cabbage under seepage irrigation relies on bare ground hills spaced $1 \mathrm{~m}$ apart with an in-row plant spacing of $20 \mathrm{~cm}$, which results in $\approx 48,438$ plants $/$ ha. A preliminary evaluation conducted in commercial cabbage fields in northeast Florida, showed that $30 \%$ of the planted population were not harvested since the cabbage heads failed to reach marketable size or were of poor quality. In vegetable production systems, plasticulture offers potential to stabilize yield by reducing the negative effects of adverse weather conditions and maximizing production per area over traditional unmulched soils (Lament, 1993).

Plasticulture cabbage production combines drip irrigation, plastic mulch, and injected liquid fertilizers (fertigation) and allows the use of higher cabbage plant populations as compared with seepage irrigation. Plasticulture has been extensively used in commercial production of high-value horticultural crops such as tomato (Solanum lycopersicum), bell pepper (Capsicum annuum), strawberry (Fragaria $\times$ ananassa), and melon (Cucumis melo) since the 1970s (Locascio, 2005). However, it has not been widely adopted for commercial fresh-market cabbage production in the United States since information is lacking on practical management and economic feasibility of plasticulture cabbage production, although it has shown potential in India (Singh, 1978; Tiwari et al., 2003). Higher cabbage plant populations achieved through the use of plasticulture has the potential for increased yield by increasing the number of marketable cabbage heads per area and by reducing the number of nonmarketable heads left in the field. Previous studies in Florida have been conducted to examine the effects of plant populations ranging from 24,600 to 123,000 plants/ha on cabbage head characteristics and marketable yield using bare ground (White and Forbes, 1976), strip mulched (Stoffella and Fleming, 1990), and full mulched beds (Csizinszky and Schuster, 1985). These previous studies demonstrated that there is potential for increased yields at higher plant populations but there is a limit, at which point head weight decreases (White and Forbes, 1976), and the variability between heads is increased (Stoffella and Flemming, 1990). With plasticulture, there is also the potential to reuse the plastic mulch and drip tape for an additional vegetable crop (Lament, 1993; Orzolek, 1996), whereby depreciation of the initial cost of material over two crops could reduce the risk of implementing this technology.

The high population plasticulture cabbage production system described in this paper was conceptualized through the cooperation of northeast Florida cabbage growers, researchers, and extension specialists at the University of Florida to incorporate as much 
of the traditional equipment, field layout, and management strategies as possible with the addition of plasticulture technology. This new system was evaluated for potential use with the understanding that in-row plant spacing and planting date can affect cabbage head weight, head density, head shape, and marketable yield (Csizinszky and Schuster, 1985; McKeown et al., 2010; Radovich et al., 2004; Stoffella and Flemming, 1990; White and Forbes, 1976). The objectives of this study were to determine the optimum cabbage plant population and plant arrangement that maximizes marketable yield per area for a high cabbage population plasticulture system.

\section{Materials and Methods}

Field experiments were conducted using the commercial cabbage cultivar Bravo grown during three growing seasons, Winter 2010 (Dec. 2010 to Apr. 2011), Fall 2011 (Oct. 2011 to Feb. 2012), and Winter 2011 (Dec. 2011 to Apr. 2012). The experimental trials were completed at the University of Florida, Institute of Food and Agricultural Sciences, Hastings Research and Extension Center in Hastings, FL. The soil was characterized as a Placid fine sand: sandy, siliceous, hyperthermic, typic, humaquepts, with $0 \%$ to $2 \%$ slopes (Readle, 1983). Cabbage was grown on 1.2-m-wide raised beds with black plastic mulch $(1.8 \mathrm{~m}$ width, $1.25 \mathrm{~mm}$ thickness, VIF film; Polygro, LLC, Safety Harbor, FL) and two drip tapes (Aqua-Traxx model EA5081222, $16 \mathrm{~mm}$ diameter, $0.3 \mathrm{~m}$ emitter spacing, $0.5 \mathrm{~L} \cdot \mathrm{h}^{-1}$ at $55 \mathrm{kPa}$; Toro Agricultural Irrigation, El Cajon, CA). Beds were spaced $2.0 \mathrm{~m}$ on center. Cabbage transplants were planted in either three or four rows per bed with an in-row spacing of $15,20,25,30$, or $35 \mathrm{~cm}$ (Fig. 1). These 10 treatment combinations (row configuration + in-row spacing) represented nine different plant populations, of which, seven were greater than the conventional bare ground plant population of 48,438 plants/ha (Table 1 ). In 2010, the treatment combinations were arranged in a split-plot experimental design with randomized complete blocks and four replications, where number of rows per bed

Received for publication 26 June 2015. Accepted for publication 3 Aug. 2015.

This research was supported by the Florida Specialty Crop Block Grant Program (contract no. 00085482) and the University of Florida Office of the Dean of Extension 2011-12 Extension Program Enhancement Grant.

We are grateful for the contribution and support of northeast Florida vegetable growers, especially Tommy Miller and Mark Barnes. We would like to thank the staff of Hastings Agricultural Extension Center, Hastings, FL: Marcelo Paranhos, David Dinkins, Mark Warren, Douglas Gergela, Bart Herrington, Thaddis Merrick, Hugh Burnham, and Patrick Moran for their assistance with field operation, sampling, and sample analysis. A special thanks to Dr. Peter Stoffella for guidance and review.

${ }^{1}$ Corresponding author. E-mail: lzota@ufl.edu.

\section{A. Transect view}
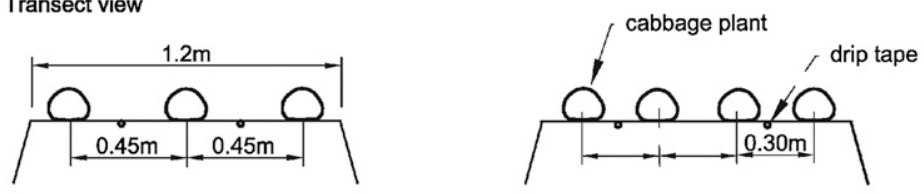

B. Aerial view

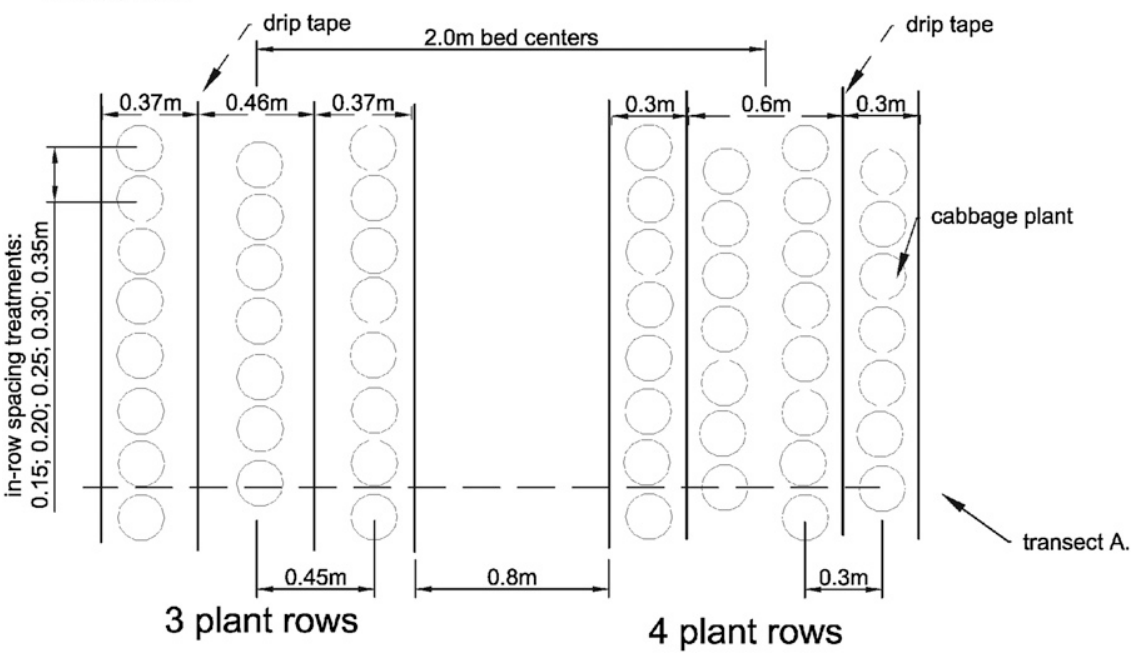

Fig. 1. Diagram of the plasticulture system tested for high population cabbage production including a transect view (top) and an aerial view (bottom), showing the 3-row configuration (left) and the 4-row configuration (right). The bed spacing and in-row plant spacings are shown in the aerial view.

was the main plot factor and in-row spacing was the subplot factor. The 2011 experimental design was changed slightly from the 2010 design to accommodate two planting dates; one in October and other in December. The basic split-plot design was maintained with randomized complete blocks and four replications, however, the main plot factor (three or four rows) was only randomized across the width of the experiment site, and because the blocks were arranged in a two by two manner, two blocks received one randomization and two received another randomization instead of all four block receiving their own randomization. Therefore, the four original replications were treated as two replications with each block consisting of two samples for data analysis. Plots were $12 \mathrm{~m}$ long and the center $6 \mathrm{~m}$ were used for data collection in both years.

Cabbage was transplanted in Winter 2010 on 3 Dec., Fall 2011 on 25 Oct., and Winter 2011 on 6 Dec. Preplant granular fertilizer was incorporated into the beds using a $10 \mathrm{~N}-$ 4.4P-8.3K material at a rate of $56 \mathrm{~kg} \cdot \mathrm{ha}^{-1}$. Fertilizer was injected through the drip tape weekly using a liquid $8 \mathrm{~N}-0 \mathrm{P}-6.4 \mathrm{~K}$ material for an accumulative application of $320 \mathrm{~N}-$ $24.5 \mathrm{P}-265.6 \mathrm{~K} \mathrm{~kg} \cdot \mathrm{ha}^{-1}$. Cabbage was harvested when the majority $(>50 \%)$ of plants of a plot reached maturity. The Winter 2010 planting was harvested 28 Mar. and 2, 7, 12, 17, and 22 Apr. 2011. The Fall 2011 planting was harvested 30 Jan. and 8, 22 Feb. 2012, whereas the Winter 2011 planting was harvested 9, 22 March and 3 Apr. 2012. Harvests were performed by cutting the stem of the plant below the outer most photosynthetic leaves (wrapper leaves) at the soil surface.
Table 1. Plant populations for row configuration and in-row plant spacing treatment combinations for a high population ${ }^{\mathrm{z}}$ plasticulture cabbage production system.

\begin{tabular}{lcc}
\hline In-row & \multicolumn{2}{c}{ Plant population (plant/ha) } \\
\cline { 2 - 3 } spacing $(\mathrm{cm})$ & 3-row & 4-row \\
\hline 15 & 96,875 & 129,167 \\
20 & 72,656 & 96,875 \\
25 & 58,125 & 77,500 \\
30 & 48,438 & 64,583 \\
35 & 41,518 & 55,357 \\
\hline
\end{tabular}

${ }^{2}$ The plant population for traditional bare ground system with seepage irrigation is $\approx 48,438$ plant $/$ ha.

Wrapper leaves were trimmed off, then cabbage heads were weighed and sorted for marketable yield, U.S. No. 1, with a range of weight between 1 and $2 \mathrm{~kg}$ per head for commercial cabbage production (U.S. Department of Agriculture, 1997). At each harvest, 10 cabbage heads were randomly selected (five from an interior row and five from an exterior row) from each plot. The selected heads were cut in half longitudinally then each head was measured for polar and equatorial diameters, core length, and core base width. The ratio of polar to equatorial diameter was then calculated (P:E). Cabbage heads were treated as a sphere for the calculation of head volume $\left(\mathrm{cm}^{3}\right)$ and cores were treated as a cone for the calculation of core volume $\left(\mathrm{cm}^{3}\right)$ following the methods described by Kleinhenz and Wszelaki (2003). Mean cabbage head weight $(\mathrm{g})$ was determined from cabbage head weights recorded at harvest. Mean cabbage head weight and volume were used to calculate density $\left(\mathrm{g} \cdot \mathrm{cm}^{-3}\right)$. The percentage of head volume occupied by the core ( $\%$ head volume) was 
calculated from the derived head and core volumes.

Data were analyzed using the GLIMMIX and REG procedures of SAS Version 9.4 (SAS Institute, Cary, NC). A two-way analysis of variance was performed for yield and head trait data. Means separation was used to examine differences between 3- and 4-row configurations within each in-row spacing treatment when the interaction of these two main effects was significant. Regression analysis was used to determine if a linear or quadratic relationship existed for in-row spacing treatments. All three seasons were treated as separate experiments for data analysis.

\section{Results}

\section{Seasonal weather conditions}

Although the duration of the harvest period was similar between the three seasons, 23 to $25 \mathrm{~d}$, the length of the growing seasons from transplanting to first harvest was $115 \mathrm{~d}$ for Winter 2010, and 97 and $94 \mathrm{~d}$ for Fall and Winter 2011, respectively. The Winter 2010 season was characterized by lower air temperatures compared with Fall and Winter 2011. The average minimum and maximum air temperatures for Winter 2010 were 6.4 and $20.6{ }^{\circ} \mathrm{C}$ as compared with Fall and Winter 2011 with 9.8 and $9.4{ }^{\circ} \mathrm{C}$ (minimum) and 22.9 and $22.8^{\circ} \mathrm{C}$ (maximum), respectively (Fig. 2). Winter 2010 experienced 17 freezing events during the first $72 \mathrm{~d}$ after transplanting, as compared with only five and seven freezing events for Fall and Winter 2011 growing seasons, respectively. The lower air temperatures extended the Winter 2010 growing season $\approx 20 \mathrm{~d}$ longer than Fall and winter 2011, promoting slower plant growth especially during the early growth stages of the crop as seen with a slower growing degree day accumulation (Fig. 2). In Winter 2010, the longer growing season extended further into April, and the crop was subjected longer day lengths and, as a result, accumulated $33 \%$ and $24 \%$ more solar radiation than Fall and Winter 2011, respectively. The Winter 2010 season also experienced more rainfall with $255 \mathrm{~mm}$ as compared with $209 \mathrm{~mm}$ (Fall 2011) and $185 \mathrm{~mm}$ (Winter 2011), although the distribution of rainfall events was similar between seasons.

\section{Marketable yield}

There were no significant differences in total number of cabbage heads harvested per area for each treatment combination between the three growing seasons $(P \leq 0.05)$, meaning that in terms of transplant survival, the treatment combinations performed similarly in all three growing seasons. While there were significant differences in the total number of heads harvested between the treatment combinations (in-row spacing and row configuration), this was anticipated as the treatment combinations relate to different plant populations (Table 1). The average number of cabbage heads harvested per cultivated area for all three seasons was 101,864;
81,$719 ; 68,273 ; 56,890$ and 48,951 heads/ha for $15,20,25,30$ and $35 \mathrm{~cm}$ in-row spacings, respectively. While the average total number of heads harvested for the 3- and 4-row configurations were 62,667 and 80,425 heads/ha, respectively.

When compared, the head weight distributions between Winter 2010, Fall 2011, and Winter 2011, the percentage of heads within the marketable $1-2 \mathrm{~kg}$ range was similar for each in-row spacing treatment (Fig. 3). There was a decrease in the percentage of unmarketable heads as in-row spacing increased. In addition, there was a decrease in the percentage of heads $>2 \mathrm{~kg}$ and an increase in unmarketable heads $<1 \mathrm{~kg}$ in Fall and Winter 2011 as compared with Winter 2010.

These findings indicated that while the total number of heads harvested within each in-row spacing treatment remained constant, the overall weight of cabbage heads was reduced during the Fall and Winter 2011 growing seasons.

Winter 2010. For the Winter 2010 growing season, there were no significant differences between the 3- or 4-row configurations and no interaction was seen between in-row plant spacing and row configuration for marketable yield. There was, however, a quadratic response to in-row plant spacing for marketable yield $(P \leq 0.01)$. The $30-\mathrm{cm}$ inrow plant spacing yielded $69.4 \mathrm{Mg} \cdot \mathrm{ha}^{-1}$, which was the highest yield, while the $15-\mathrm{cm}$ in-row spacing produced the lowest marketable yield (Table 2).
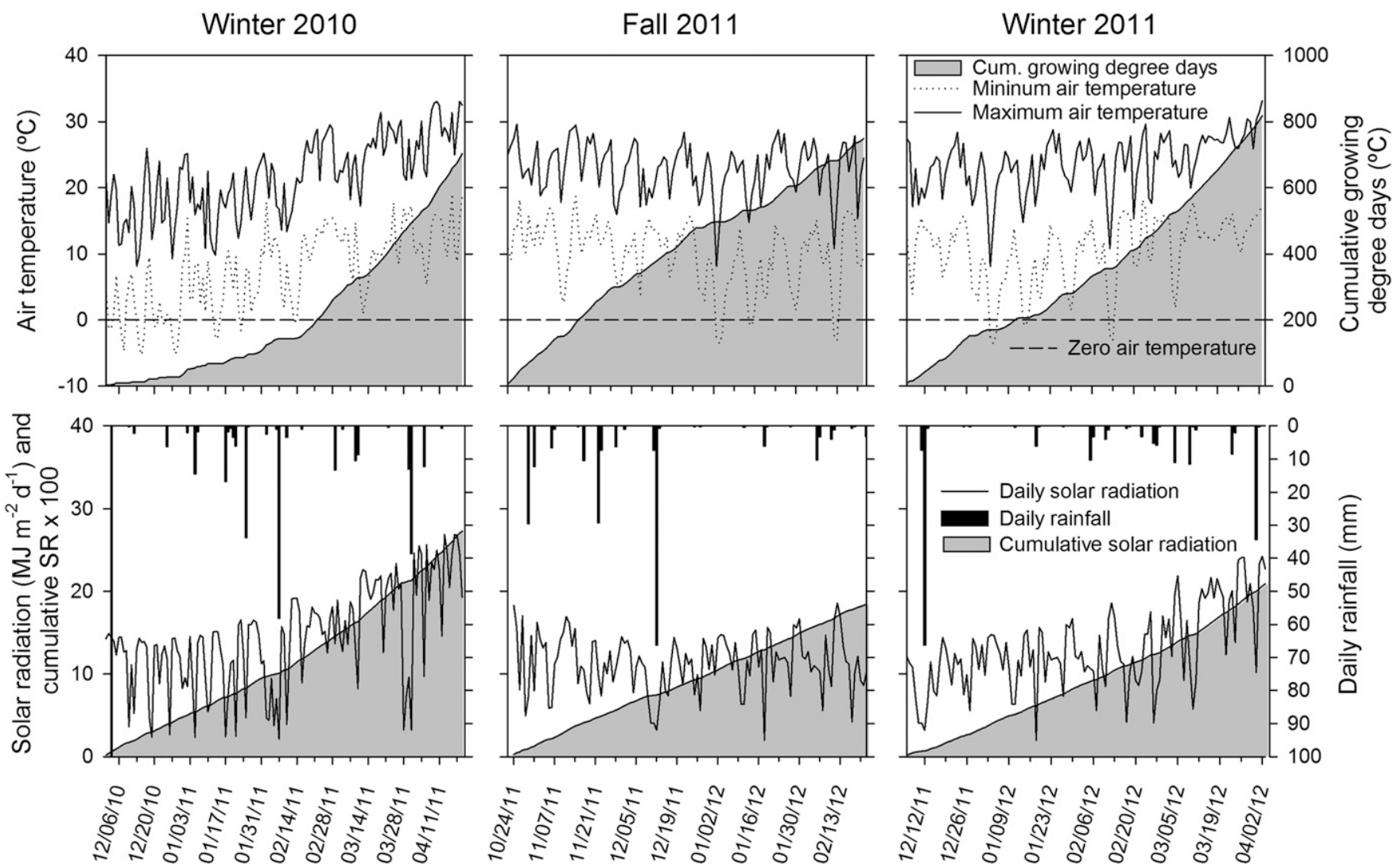

Fig. 2. Maximum and minimum daily air temperatures with cumulative growing degree days (base temperature $10^{\circ} \mathrm{C}$, with $0{ }^{\circ} \mathrm{C}$ at the day before transplanting) and daily rainfall with daily and cumulative solar radiation for all three growing periods. Data source: Florida Automated Weather Network (<http://fawn.ifas. ufl.edu/>). 
Fall and Winter 2011. There was an overall reduction in marketable yield of $34 \%$ and $41 \%$ for Fall and Winter 2011, respectively, compared with Winter 2010 (Table 2). There were significant interactions between in-row spacing and row configuration in Fall $(P \leq 0.01)$ and Winter $(P \leq 0.01) 2011$ for marketable yield (Table 2). In Fall 2011, marketable yield did not differ between in-row spacing treatments for the 3-row configuration. Marketable yield increased quadratically as in-row spacing increased within the 4-row configuration. In Winter 2011, marketable yield also responded quadratically for the 3-row configuration and linearly for the 4-row configuration as in-row plant spacing increased (Table 2).

The $15-\mathrm{cm}$ in-row spacing produced a lower marketable yield compared with all other plant spacings in Fall 2011 with a 26\% reduction compared with the average of the other in-row spacing treatments (Table 2). Similarly, both the $15-$ and $20-\mathrm{cm}$ spacing treatments resulted in lower marketable yields compared with the average of the other plant spacings for Winter 2011 with $49 \%$ and $20 \%$ reductions in yield, respectively.

Marketable yield was not different in the Fall 2011 growing season between 3- and 4-row configurations with 49.9 and $49.5 \mathrm{Mg} \cdot \mathrm{ha}^{-1}$, respectively. However, in the Winter 2011 growing season, the 4-row configuration produced $15 \%$ lower marketable yields (41.1 Mg.ha ${ }^{-1}$ ) than the 3-row configuration (48.1 Mg.ha ${ }^{-1}$ ).

The 15- and $20-\mathrm{cm}$ in-row spacing treatments also produced significantly lower yields in the 4-row configuration as compared with the 3-row configuration in Fall and Winter 2011.

\section{Cabbage head traits}

Winter 2010. In the Winter 2010 growing season, there was an interaction $(P \leq 0.01)$ between in-row plant spacing and row configuration for head weight. Head weight increased linearly as in-row spacing increased in both 3- and 4-row configurations (Table 3).

Average head weight was similar between 3 - and 4-row configurations for in-row plant spacings $\geq 25 \mathrm{~cm}$, but the 4-row 15 - and 20 -cm in-row spacing treatments produced significantly lower head weight than all other inrow spacing and row configuration treatment combinations.

In-row plant spacing had a significant effect $(P \leq 0.01)$ on head density, polar diameter $(P \leq 0.01)$, and the percentage of head volume occupied by the core $(P \leq 0.01)$. Cabbage head density increased linearly as inrow spacing increased in Winter 2010 (Table 4).

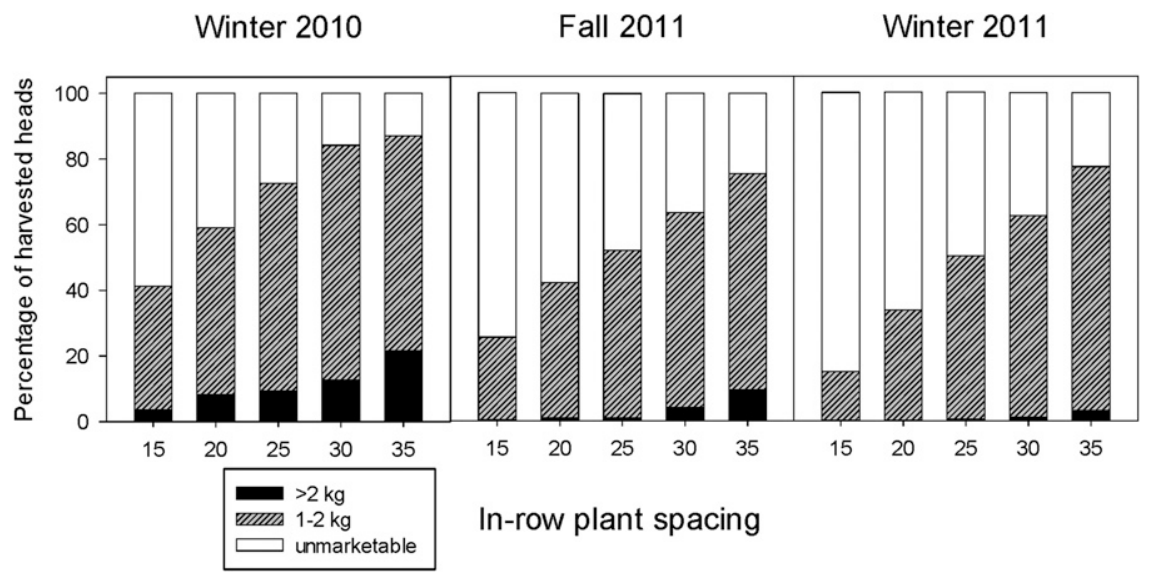

Fig. 3. Percentage of total cabbage heads harvested within each size range $>2 \mathrm{~kg}, 1-2 \mathrm{~kg}$, and unmarketable $(<1$ $\mathrm{kg}$ ) for each in-row plant spacing (3- and 4-row combined) for Winter 2010, Fall and Winter 2011.

Table 2. Marketable cabbage yield $\left(\mathrm{Mg} \cdot \mathrm{ha}^{-1}\right)$ for the main effect of in-row plant spacings (Winter 2010) and the interaction effect of in-row plant spacings and row configurations (Fall and Winter 2011) cultivated on a 1.2 -m-wide plastic mulch system.

\begin{tabular}{|c|c|c|c|c|c|}
\hline \multirow[b]{3}{*}{ In-row spacing $(\mathrm{cm})$} & \multicolumn{5}{|c|}{ Marketable yield ${ }^{\mathrm{z}}\left(\mathrm{Mg} \cdot \mathrm{ha}^{-1}\right)$} \\
\hline & \multirow[b]{2}{*}{ Winter $2010^{y}$} & \multicolumn{2}{|c|}{ Fall $2011^{x}$} & \multicolumn{2}{|c|}{ Winter 2011 } \\
\hline & & 3 rows & 4 rows & 3 rows & 4 rows \\
\hline 15 & 53.4 & $40.9 \mathrm{~A}$ & $37.1 \mathrm{~A}$ & $32.7 \mathrm{~A}$ & $19.7 \mathrm{~B}$ \\
\hline 20 & 64.9 & $54.2 \mathrm{~A}$ & $48.4 \mathrm{~B}$ & $51.0 \mathrm{~A}$ & $32.2 \mathrm{~B}$ \\
\hline 25 & 69.0 & $52.8 \mathrm{~A}$ & $53.0 \mathrm{~A}$ & $51.0 \mathrm{~A}$ & $49.4 \mathrm{~A}$ \\
\hline 30 & 69.4 & $48.4 \mathrm{~A}$ & $53.1 \mathrm{~A}$ & $54.7 \mathrm{~A}$ & $49.3 \mathrm{~A}$ \\
\hline \multirow[t]{2}{*}{35} & 66.7 & $53.3 \mathrm{~A}$ & $55.7 \mathrm{~A}$ & $51.4 \mathrm{~A}$ & $54.8 \mathrm{~A}$ \\
\hline & $\mathrm{Q}^{* *}$ & NS & $\mathrm{Q}^{* *}$ & $\mathrm{Q}^{* *}$ & $\mathrm{~L}^{* *}$ \\
\hline
\end{tabular}

${ }^{\mathrm{z}}$ Regression analysis for the effect of in-row spacing.

${ }^{y}$ The interaction between in-row spacing and row configuration was not significant for Winter 2010.

${ }^{x}$ Values followed by the same uppercase letter within each in-row spacing indicate mean marketable cabbage yield was not significantly different $(P \leq 0.05)$ when comparing 3 - and 4-row configuration for Fall and Winter 2011 with mean separation by Tukey-Kramer test.

${ }^{\mathrm{N}}$ Not significant for $\mathrm{L}$ or $\mathrm{Q}$.

$* * P<0.01$.

$\mathrm{L}=$ linear; $\mathrm{Q}=$ quadratic
There was a linear increase in cabbage polar diameter as in-row plant spacing increased (data not shown), however, no differences were seen for head equatorial diameter. There was a decrease in the percentage of head volume occupied by the core as in-row plant spacing increased; however, all treatment combinations yielded core volumes that were $\approx 1 \%$ of total head volume.

Fall and Winter 2011. There was no interaction between in-row spacing and row configuration for cabbage head weight in both Fall and Winter 2011 (Table 5). The row configuration and in-row spacing interaction was only significant for cabbage head volume $(P \leq 0.01)$ and head polar diameter $(P \leq 0.01)$ for the Fall 2011 season (Table 6). In-row spacing had a significant effect on head volume for Winter 2011 ( $P \leq 0.01)$, head polar diameter for Winter $2011(P \leq 0.01)$, and head equatorial diameter in Fall $2011(P \leq 0.01)$ and Winter $2011(P \leq 0.01)$.

Similar to the Winter 2010 season, cabbage head density increased linearly as inrow plant spacing increased in Fall 2011, and a quadratic response was observed in Winter 2011 (Table 4). Row configuration also had a significant $(P \leq 0.01)$ effect on head density in the Winter 2011 growing season. The head densities were 0.84 and $0.77 \mathrm{~g} \cdot \mathrm{cm}^{-3}$ for 3-and 4-row configurations, respectively.

Cabbage head weight increased linearly as in-row plant spacing increased for the Fall and Winter 2011 growing seasons (Table 5). Average head weight was significantly higher for the 3-row configuration (1075 and $1083 \mathrm{~g}$ ) as compared with the 4-row configuration (984 and $924 \mathrm{~g}$ ) for both fall and Winter 2011, respectively.

There was an overall increase of cabbage head volume and head diameter parameters with the increase of in-row spacing. Head volume increased as in-row spacing increased for both Fall and Winter 2011 (Table 6). In Fall 2011, head volume of the 3-row configuration responded linearly while the 4-row configuration responded quadratically to the increase of in-row spacing (Table 6). In the

Table 3. Effects of the interaction between in-row spacing $(\mathrm{cm})$ and row configuration on average cabbage head weight ( $\mathrm{g} / \mathrm{head})$ for the Winter 2010 season cultivated on 1.2 -m-wide plastic mulch system.

\begin{tabular}{lcr}
\hline & \multicolumn{2}{c}{ Head wt $^{\text {zy }}(\mathrm{g} / \mathrm{head})$} \\
\cline { 2 - 3 } In-row spacing $(\mathrm{cm})$ & 3 rows & 4 rows \\
\hline 15 & $1,060 \mathrm{~A}$ & $853 \mathrm{~B}$ \\
20 & $1,251 \mathrm{~A}$ & $1,002 \mathrm{~B}$ \\
25 & $1,300 \mathrm{~A}$ & $1,206 \mathrm{~A}$ \\
30 & $1,409 \mathrm{~A}$ & $1,331 \mathrm{~A}$ \\
35 & $1,509 \mathrm{~A}$ & $1,459 \mathrm{~A}$ \\
& L** & L** \\
\hline zValues followed by the same uppercase letter within
\end{tabular}
the same in-row spacing treatment indicate mean head weight was not significantly different $(P \leq$ 0.05 ) between row configurations with means separation by Tukey-Kramer test.

${ }^{\mathrm{y}}$ Regression analysis for the effect of in-row spacing.

$* * P<0.01$

$\mathrm{L}=$ linear. 
Table 4. Cabbage head density as affected by in-row pant spacing in Winter 2010 and in Fall and Winter 2011.

\begin{tabular}{lccc}
\hline In-row & \multicolumn{3}{c}{ Cabbage head density ${ }^{\text {zy }}\left(\mathrm{g} \cdot \mathrm{cm}^{-3}\right)$} \\
spacing $(\mathrm{cm})$ & Winter 2010 & Fall 2011 & Winter 2011 \\
\hline 15 & 0.65 & 0.68 & 0.67 \\
20 & 0.72 & 0.76 & 0.81 \\
25 & 0.81 & 0.81 & 0.86 \\
30 & 0.79 & 0.89 & 0.83 \\
35 & 0.86 & 0.93 & 0.86 \\
& $\mathrm{~L}^{* *}$ & $\mathrm{~L}^{* *}$ & $\mathrm{Q}^{* *}$ \\
\hline
\end{tabular}

${ }^{2}$ Regression analysis for the effect of in-row spacing.

${ }^{y}$ The interaction between in-row spacing and row configuration was not significant for head density in any season, therefore, means separation was not performed.

$* * P<0.01$.

$\mathrm{L}=$ linear; $\mathrm{Q}=$ quadratic.

Table 5. Effects of in-row spacing on cabbage head weight $(\mathrm{g} / \mathrm{head})$ for the Fall and Winter 2011 growing seasons.

\begin{tabular}{lcc}
\hline In-row & \multicolumn{2}{c}{ Head $\mathrm{wt}^{\text {zy }}(\mathrm{g} / \mathrm{head})$} \\
\cline { 2 - 3 } spacing $(\mathrm{cm})$ & Fall 2011 & Winter 2011 \\
\hline 15 & 797 & 765 \\
20 & 921 & 943 \\
25 & 1,007 & 1,027 \\
30 & 1,154 & 1,076 \\
35 & 1,271 & 1,205 \\
& $\mathrm{~L}^{* *}$ & $\mathrm{~L}^{* *}$ \\
\hline
\end{tabular}

${ }^{\text {RRegression analysis for the effect of in-row }}$ spacing.

${ }^{\mathrm{y}}$ The interaction between in-row spacing and row configuration was not significant for head density in either season, therefore, means separation was not performed.

$* * P<0.01$

$\mathrm{L}=$ linear.

Winter 2011 season, head volume increased linearly as in-row spacing increased. Row configuration also had a significant $(P \leq$ 0.01 ) effect on cabbage head volume in Winter 2011. The average head volumes were 1285 and $1196 \mathrm{~cm}^{3}$ for 3- and 4-row configurations, respectively.

Head polar diameter increased linearly as in-row spacing increased in the 3-row configuration and quadratically in the 4-row configuration during Fall 2011 (Table 6). Row configuration also had a significant effect $(P \leq 0.01)$ on head polar diameter in Winter 2011. The average head polar diameters were 13.2 and $12.7 \mathrm{~cm}$ for 3 - and 4-row configurations, respectively.

Head equatorial diameters increased linearly as in-row spacing increased for both the Fall and Winter 2011 seasons. There was no interaction between row configuration and in-row spacing for either season. Row configuration had a significant $(P \leq 0.01)$ effect on head equatorial diameter in Fall 2011. The head equatorial diameters were 14.0 and $13.7 \mathrm{~cm}$ for 3- and 4-row configurations, respectively.

The P:E was not found to be significantly affected by any treatment or interactions between treatment combinations. This suggested that while minor differences $(<1 \mathrm{~cm})$ can be seen between treatments and interactions for separate polar or equatorial dimensions, these differences are insignificant with reference to overall head shape. In this study, the cabbage variety Bravo produced consistent head shape regardless of the inrow spacing, row configuration, growing season, or the interactions thereof.

Differences seen in core length, core base width, core volume, and the percent head volume occupied by the core were rare. In Winter 2011, there was a significant effect of in-row plant spacing $(P \leq 0.01)$ and row configuration $(P \leq 0.01)$ on the percent head volume occupied by the core; however, all means were $\approx 1 \%$ of the total head volume.

\section{Discussion}

Cabbage is sensitive to day length and air temperature; therefore, some variability in cabbage marketable yield is expected across seasons and years. Wszelaki and Kleinhenz (2003) reported that year and growing season had a significant effect on marketable yield, average head weight, head volume, head density, head polar diameter, head shape, and core base width for the cultivar Bravo. The optimal average air temperature range for cabbage has been reported as between 16 and $21{ }^{\circ} \mathrm{C}$ and when air temperatures are outside that range growth can be slow and irregular (Boswell and Jones, 1941; Criddle et al., 1997; Hara and Sonoda, 1982). A comparison of weather patterns for the Winter 2010, Fall 2011, and Winter 2011 growing seasons showed that Winter 2010 presented much more favorable conditions for cabbage plant growth (Fig. 2). In fact, the effect of above average air temperature was evident in both Fall and Winter 2011 growing seasons, as the number of days required to obtain harvestable heads was reduced by $16 \%$ and $18 \%$ (Fig. 2) and marketable yields were on average $34 \%$ and $42 \%$ lower than Winter 2010 , respectively (Table 2). Fall and Winter 2011 had higher average minimum and maximum air temperatures with $69 \mathrm{~d}$ each with high temperatures over $21{ }^{\circ} \mathrm{C}$ compared with $58 \mathrm{~d}$ in the longer Winter 2010 season. The number of hours of air temperature above $25{ }^{\circ} \mathrm{C}$ was $133 \mathrm{~h}$ in Winter 2010, $141 \mathrm{~h}$ in Fall 2011, and $247 \mathrm{~h}$ in Winter 2011. These higher average air temperatures and more days with maximum contributed to the overall reduced yields seen in Fall and Winter 2011 compared with Winter 2010. In conjunction with air temperature, solar radiation availability also played air temperatures over $21{ }^{\circ} \mathrm{C}$ may have an important role in cabbage productivity when Fall and Winter 2011 were compared. After the early head formation stage, there was more solar radiation available to the crop in the winter seasons (Fig. 2). Larger in-row plant spacings can reduce interplant competition in high-density cabbage production, thereby helping to maintain marketable yield and maximize marketablesized cabbage head production, even in years with less favorable growing conditions. Similar results were reported in 2 of 3 years in Ontario, Canada, where in 2003-04 lower air temperatures led to longer growing seasons and increased yields as compared with 2005 (McKeown et al., 2010).

Differences in marketable cabbage yield between years is not uncommon in the literature, for example in Florida, Stoffella and Flemming (1990) reported trimmed head yields for 'Bravo' that were on average 30\% lower in 1987 compared with 1988 , but did not report weather differences between years. The differences in marketable yield seen between Fall 2011 and Winter 2011 were most apparent at the narrowest two plant spacings (15 and 20 $\mathrm{cm}$ ) and therefore the highest plant populations. The rapid increase in air temperature and solar radiation availability that occurred with the onset of spring coincided with head development in Winter 2011, meanwhile, the head development of the Fall 2011 crop coincided with mild winter conditions, and this difference in the timing of season change may have led to the differences in yield observed between these two seasons.

Cabbage heads grow larger (Csizinszky and Schuster, 1985; Stoffella and Fleming, 1990; White and Forbes, 1976) at an increased rate (Stoffella and Fleming, 1990) at greater in-row plant spacings than at reduced spacings. Cabbage head weight in this study responded with a positive linear relationship to increasing in-row plant spacing in all the three growing seasons (Tables 3 and 5). Greater in-row spacings also produced a lower percentage of unmarketable $(<1 \mathrm{~kg})$ cabbage heads (Fig. 3), which led to increased marketable yield when compared with narrower plant spacings. Cabbage head weight was larger in the Winter 2010 season than in both growing seasons in 2011 (Tables 3 and 5). This trend is also illustrated by both seasons having a similar percentage of heads in the $1-2 \mathrm{~kg}$ size class (Fig. 3) but very different marketable yields (Table 2).

For all in-row spacing treatments examined except the $15 \mathrm{~cm}$, mean cabbage head density in this study was typically greater than $0.70 \mathrm{~g} \cdot \mathrm{cm}^{-3}$, which is considered acceptable for marketability (Isenberg et al., 1975; Kleinhenz and Wszelaki, 2003; Stoffella and Fleming, 1990). For all the three seasons, head volume and head diameter (both polar and equatorial) followed a similar trend as head weight and increased as in-row spacing increased. No consistent differences in 
Table 6. Interactive effects of in-row spacing $(\mathrm{cm})$ and row configuration on cabbage head volume $\left(\mathrm{cm}^{3}\right)$ and polar head diameter $(\mathrm{cm})$ for Fall 2011 and the main effect of in-row spacing on head volume, polar head diameter, and equatorial head diameter for cabbage grown during Fall and Winter 2011 on a 1.2-m-wide plastic mulch system.

\begin{tabular}{|c|c|c|c|c|c|c|c|c|}
\hline \multirow[b]{4}{*}{ In-row spacing $(\mathrm{cm})$} & \multirow{2}{*}{\multicolumn{3}{|c|}{ Head vol ${ }^{\mathrm{z}}\left(\mathrm{cm}^{3}\right)$}} & \multicolumn{5}{|c|}{$\operatorname{Head~diam}^{\mathrm{z}}(\mathrm{cm})$} \\
\hline & & & & \multicolumn{3}{|c|}{ Polar } & \multirow{2}{*}{\multicolumn{2}{|c|}{ Equatorial }} \\
\hline & \multicolumn{2}{|c|}{ Fall $2011^{\mathrm{y}}$} & \multirow[b]{2}{*}{ Winter 2011} & \multicolumn{2}{|c|}{ Fall $2011^{y}$} & \multirow[b]{2}{*}{ Winter 2011} & & \\
\hline & 3-row & 4-row & & 3-row & 4-row & & Fall 2011 & Winter 2011 \\
\hline 15 & $1,155 \mathrm{~A}$ & $1,190 \mathrm{~A}$ & 1,144 & $12.5 \mathrm{~A}$ & $12.8 \mathrm{~A}$ & 12.6 & 13.5 & 13.3 \\
\hline 20 & $1,276 \mathrm{~A}$ & $1,155 \mathrm{~B}$ & 1,167 & $13.0 \mathrm{~A}$ & $12.6 \mathrm{~B}$ & 12.7 & 13.7 & 13.4 \\
\hline 25 & $1,296 \mathrm{~A}$ & $1,204 \mathrm{~A}$ & 1,202 & $13.1 \mathrm{~A}$ & $12.7 \mathrm{~B}$ & 12.8 & 13.8 & 13.5 \\
\hline 30 & $1,368 \mathrm{~A}$ & $1,233 \mathrm{~B}$ & 1,292 & $13.2 \mathrm{~A}$ & $12.9 \mathrm{~A}$ & 13.2 & 14.0 & 13.9 \\
\hline 35 & $1,386 \mathrm{~A}$ & $1,346 \mathrm{~A}$ & 1,400 & $13.3 \mathrm{~A}$ & $13.4 \mathrm{~A}$ & 13.5 & 14.2 & 14.3 \\
\hline & $\mathrm{L}^{* *}$ & $\mathrm{Q}^{* *}$ & $\mathrm{~L} * *$ & $\mathrm{~L}^{* *}$ & $\mathrm{Q}^{* *}$ & $\mathrm{~L}^{* *}$ & $\mathrm{~L}^{* *}$ & $\mathrm{~L}^{* *}$ \\
\hline
\end{tabular}

${ }^{\mathrm{z}}$ Regression analysis for the effect of in-row spacing.

${ }^{y}$ Values followed by the same uppercase letter within the same in-row spacing indicate that the mean cabbage head volume or head diameter are not significantly different $(P \leq 0.05)$ between 3-row and 4-row configurations for Fall 2011 with means separation by Tukey-Kramer test.

$* * P<0.01$.

$\mathrm{L}=$ linear; $\mathrm{Q}=$ quadratic.

core base width and core length were seen between treatments in either year, and core volume was on average only $\approx 1 \%$ of the total head volume. Similar results were seen for Bravo in the work by Wszelaki and Kleinhenz (2003), where core length and core base width were not significantly different for May compared with June-July planting dates in Ohio. In that same study, the percent head volume occupied by the core was affected by planting date but this was an effect of significantly larger head volume in May as compared with June-July and not because of differences in core volume as they were the same for both planting dates.

Having had two different years, in terms of growing conditions, presented a unique opportunity to evaluate in-row plant spacing and row configuration for superior performance regardless of climate variability. In northeast Florida, fresh-market cabbage follow the U.S. Dept. Agr. grade U.S. No. 1 with a range of weight between 2 and $4 \mathrm{lb}$ ( 1 to $2 \mathrm{~kg}$ ) per head for commercial cabbage production (U.S. Department of Agriculture, 1997), and because commercial transactions are conducted on a product weight basis, not by number of heads, cabbage heads weighing closer to $2 \mathrm{~kg}$ are more profitable. In determining the optimum row configuration and in-row spacing for a plasticulture system, it is important to select a combination that maximizes potential marketable head production.

Overall, increased in-row plant spacings produced greater marketable yield, head weight, and head density for both the 3- and 4-row configurations. A 3- or 4-row configuration with an in-row spacing between 25 and $35 \mathrm{~cm}$ has shown to be desirable because this range maximized the production of 1 to $2 \mathrm{~kg}$ sized heads, while minimizing heads above and below this size range (Fig. 3). These inrow plant spacing and row configuration combinations represent a range of plant populations of 41,518-77,500 plants/ha and a net difference in population compared the traditional bare ground system of $-14 \%$ to $60 \%$. It should be noted that although one benefit of plasticulture is the potential to increase yield by increasing plant population per area, the 3-row configuration with an in-row spacing of $35 \mathrm{~cm}$ combination represents a plant population of 41,518 plants/ha; while the 3 -row and $30 \mathrm{~cm}$ inrow spacing combination and the traditional bare ground plant population are identical with 48,438 plants/ha. Thus, the 3 -row and $35 \mathrm{~cm}$ combination represents a $14 \%$ reduction in population compared with bare ground, but as seen in both Fall and Winter 2011, there were no differences in yield between plant spacings greater than $25 \mathrm{~cm}$ in both seasons because of poor growing conditions. This combined with a reduction in percentage of unmarketable heads seen at wider in-row plant spacings (Fig. 3) suggested that lower plant populations could be more profitable in years with warmer air temperatures and therefore shorter growing seasons.

The results from these trials indicated that with a high population plasticulture system variable plant populations could be selected depending on planting date and expected weather conditions during the growing season. As in northeast Florida, the planting season typically begins in September and ends in December, in-row plant spacings of 30 and $35 \mathrm{~cm}$ might be beneficial for early plantings dates. While for later planting dates, cabbage plant population might be increased by reducing the in-row plant spacing to $25 \mathrm{~cm}$, especially under favorable weather conditions for cabbage growth. As weather and climate forecasting capabilities progress, the information presented in this study could be used to help maximize marketable cabbage production by adjusting plant populations in accordance to predicted weather patterns. Future research should consider the yield differences between bare ground seepage and plasticulture drip-irrigated systems from the perspective of input costs, with regard to plant population and cultural practices, to determine the economic feasibility of using plasticulture for cabbage production. This 2-year study was performed with one cabbage variety, future studies should compare various cabbage varieties to elucidate varieties that perform best with high populations using plasticulture production techniques.

\section{Literature Cited}

Boswell, V.R. and H.A. Jones. 1941. Climate and vegetable crops, p. 373-399. In: Climate and man (1941 yearbook of agriculture). U.S. Dept. Agr., Washington, DC.

Cordell, D., J.-O. Drangert, and S. White. 2009. The story of phosphorus: Global food security and food for thought. Glob. Environ. Change 19:292-305.

Criddle, R.S., B.N. Smith, and L.D. Hansen. 1997. A respiration based description of plant growth rate responses to temperature. Planta 201:441445.

Csizinszky, A.A. and D.J. Schuster. 1985. Response of cabbage to insecticide schedule, plant spacing, and fertilizer rates. J. Amer. Soc. Hort. Sci. 110:888-893.

Dukes, M.D., L. Zotarelli, and K.T. Morgan. 2010. Use of irrigation technologies for vegetable crops in Florida. HortTechnology 20:133-142.

Florida Department of Agriculture and Consumer Services. 2014. Florida agriculture by the numbers 2013. Florida Dept. Agr. and Consumer Serv., Tallahassee, FL.

Hara, T. and Y. Sonoda. 1982. Cabbage-head development as affected by nitrogen and temperature. Soil Sci. Plant Nutr. 28:109-117.

Isenberg, F.M.R., A. Pendergress, J.E. Carrol, L. Howell, and E.B. Oyer. 1975. The use of weight, density, heat units, and solar radiation to predict the maturity of cabbage for storage. J. Amer. Soc. Hort. Sci. 100:313-316.

Kleinhenz, M.D. and A. Wszelaki. 2003. Yield and relationships among head traits in cabbage as influenced by planting date and cultivar. I. Fresh market. HortScience 38:1349-1354.

Lament, W.J. 1993. Plastic mulches for the production of vegetable crops. HortTechnology 3:35-39.

Locascio, S.J. 2005. Management of irrigation for vegetables: Past, present, and future. HortTechnology 15:482-485.

Marella, R.L. 2014. Water withdrawals, use, and trends in Florida, 2010. U.S. Geological Survey Scientific Rpt. U.S. Geological Survey, Reston, VA.

McKeown, A.W., S.M. Westerveld, and C.J. Bakker. 2010. Nitrogen and water requirements of fertigated cabbage in Ontario. Can. J. Plant Sci. 90:101-109. 
Orzolek, M.D. 1996. Stand establishment in plasticulture systems. HortTechnology 6:181-185.

Radovich, T.J.K., M.D. Kleinhenz, and N.J. Honeck. 2004. Important cabbage head traits and their relationships at five points in development. J. Veg. Crop Production 10:19-32.

Readle, E.L. 1983. Soil survey of St. Johns County, Florida. Washington, D.C.

Singh, S.D. 1978. Effects of planting configuration on water use and economics of drip irrigation systems. Agron. J. 70:951-954.
Stoffella, P.J. and M.F. Fleming. 1990. Plant population influences yield variability of cabbage. J. Amer. Soc. Hort. Sci. 115:708-711.

Strandberg, J.O. and J.M. White. 1979. Estimating fresh market cabbage maturity dates in a winter production area. Proc. Fla. State Hort. Soc. 92:96-99.

Tiwari, K.N., A. Singh, and P.K. Mal. 2003. Effect of drip irrigation on yield of cabbage (Brassica oleracea L. var. capitata) under mulch and nonmulch conditions. Agr. Water Mgt. 58:19-28.
U.S. Department of Agriculture. 1997. United States standards for grades of cabbage. U.S. Dept. Agr., Washington, DC.

White, J.M. and R.B. Forbes. 1976. Effect of spacing and fertilizer rates on cabbage yield and head weight. Proc. Fla. State Hort. Soc. 89:118-120.

Wszelaki, A. and M.D. Kleinhenz. 2003. Yield and relationships among head traits in cabbage as influenced by planting date and cultivar. II. Processing. HortScience 38:1355-1359. 